\title{
Kozioł ofiarny w fursuitcie. Hierarchia $w$ fandomach na przykładzie furry
}

\section{The scapegoat in furrysuit: Fandom hierarchies as exemplified by the status of the furry fandom}

DOI: 10.12775/LL.2.2021.003 | CC BY-ND 3.0 PL

\begin{abstract}
The following article attempts to demonstrate how fandoms can be regarded as communities which - despite the initial diagnosis and findings of scholars - are based on prestige social hierarchies dependent on several factors. By analyzing the case of the furry fandom (a subculture revolving around anthropomorphic animal characters), which appears to occupy a lowly position in the aforementioned hierarchy, the author discusses the selected factors, with particular emphasis on the normativity of expression in the context of mainstream patriarchal culture permeating most fandoms.
\end{abstract}

KEYWORDS: fandom, furry, social hierarchies, normativity, social prestige

- No furrysy? Nie wiecie? Takie zbolki, co przebieraja się za zwierzęta [...]. Raz w miesiącu wynajmuja cały lokal, jak na wesele, full wypas, wszyscy w strojach, głównie takie całe kudłate [...], szopy, psy, tygrysy, cate zoo [...].

- Futrzaki. Fetyszyści. Miłośnicy antropomorficznych zwierzat, jak tego D’Artagnana, co był psem. Albo, eee, W 80 dni dokoła świata? 
- Fapia do tego?

- Eee, to siedzi gtębiej, z tego, co czytałam [...], oni się czuja tymi zwierzętami, Furrys przebiera się za jakieś zwierzę, by wyrazić swoja prawdziwa naturę...

- Psojebcy!

(Wiśniewski, 2014a, s. 51-52)

Na pytanie: „Co sądzicie o furasach?” członkowie jednej z facebookowych grup poświęconych fandomom i popkulturze, kładącej zresztą nacisk na otwarty i tolerancyjny światopogląd użytkowników, odpowiadali w następujący sposób:

Nie chcę o nich myśleć.

Pornosy robią nawet śmieszne ale jako subkultura to ich trochę się boję i uważam że należało by mieć ich na oko. Also z jakiś powodów są straszliwie podatni na bycie homoseksualnymi nazistami [...] To jest chyba grupa która bardzo łatwo wpada w ekstrema, w szczególności że są jakoś mega online [...].

Mam lęki. Dla mnie treści erotyczne z furrasami to serio taka zoofilia XD.

Nie wiem dla mnie podniecanie się byciem człekopodobnym zwierzęciem jest pierdolniete i nawet nie bede tego ubierac w ladneslowa XD nie chciałabym mieć blizszego kontaktu z furrasmi, bo sie zwyczajnie boje tego co maja we łbach.

Paskudna plama na ewolucji człowieczeństwa, gorsi (ale tylko odrobine) od stupkarzy [fetyszystów stóp - dop. A.S.].

I koleżanka na studiach rysowała furry porno za dolary, dobry hajs z tego podobno był.

Jak ktoś wydaje tyle hajsu na strój zwierzakoluda [fursuit - dop. A.S.] to musi być trochę pierdolnięty. [...] Cosplay, figurkowanie [...] itp. są formą ekspresji artystycznej [...] i hobby, furrasy to bardziej fetysz niz hobby.

Furasy to podobny tier pojebów co katolicy, jebać i szkalować [...] jeśli nie widzicie problemu w zoofilii, to zastanówcie się dwa razy.

Utylizować ${ }^{2}$.

1 Furasi to spolszczenie terminu określającego osoby $\mathrm{z}$ fandomu furry, niekiedy nazywane również futrzakami lub furrysami.

2 Jeśli nie oznaczono inaczej, wszystkie cytowane w artykule wypowiedzi pochodzą z postów umieszczonych na platformie Facebook w prywatnej grupie NRD 2.o. Zachowano oryginalna pisownię i zanonimizowano wypowiedzi użytkowników. 
Oczywiście, trudno stwierdzić, ile w tego typu wypowiedziach rzeczywistej nienawiści, a ile niechęci wywołanej ogólnym wizerunkiem tego fandomu, opartym na plotkach i doniesieniach o najbardziej ekstremalnych zachowaniach jego członków. Część komentujących zwróciła zresztą uwagę na tę kwestię:

Nie znam środowiska od wewnątrz a jedyne co słyszałem z zewnątrz to, że sporo z nich bzyka się na konwentach na potęgę. Ale równie dobrze to mogą być tylko plotki.

Wszystko co słyszałem w jakimś stopniu wiązało się z seksem, promiskuityzmem wśród członków subkultury, większą reprezentacją osób homoseksualnych i biseksualnych, powszechnym zainteresowaniem furasową pornografią, a z takich raczej już nieneutralnych plotek - większym procentem zakażonych HIV i chorych na AIDS.

Ludzie jak ludzie, znam i zjebanych i spoko, poza tym dzięki nim 16-letnie maćki, fany warhammera maja na czym wyładowywać frustrację $\mathrm{w}$ internetach.

Mogę tylko dodać, że od lat widzę sporo nieproszonego jechania po furries, więc w sumie się nie dziwię, że ludzie mają potem kontakty z najgorszymi jednostkami, prawdopodobnie to może po prostu zniechęcać sympatyczniejsze osoby do ujawniania się.

Tylko w tym jednym wątku na temat futrzaków, gdzie wypowiadają się osoby głównie spoza tego środowiska, pojawia się większość popularnych przesądów o fandomie furry, zgodnie z którymi furasy to: 1) osoby rozbuchane seksualnie, w dodatku nieheteronormatywne; 2) „nienormalni” fetyszyści; 3) grupa podatna na ekstrema, wydająca zaskakująco dużo pieniędzy na przedmioty bezsensowne (kostiumy, pornograficzne rysunki). $Z$ takim stereotypem furry w swoich badaniach polemizowali m.in. psycholog Kathleen Gerbasi (2008) czy historyk fandomów Fred Patten (2017). W niniejszym artykule nie mam zamiaru rozstrzygać, na ile wyżej wymienione zachowania są typowe dla tej grupy, chce natomiast przedstawić hipotezę wyjaśniającą, dlaczego narracje wartościujące są potrzebne ogółowi społeczności fanowskich. Zacznijmy jednak od ustaleń definicyjnych. Część swoich spostrzeżeń opierać będę na autoetnograficznych obserwacjach i doświadczeniach poczynionych w różnych środowiskach fanowskich, których członkiem jestem od ponad 20 lat. Fanoznawcy ${ }^{3}$, podobnie jak badacze popkultury, często mają problem z dokładnym zdefiniowaniem obszaru swojej naukowej refleksji; przyczyną tego jest zaś powszechność, różnorodność

3 Tego terminu, naprzemiennie $\mathrm{z}$ fantropologami, używam do określenia badaczy z dziedziny fan studies, głównie w celach stylistycznych. Również dlatego korzystam z synonimów słowa „fan”, takich jak „entuzjasta”, „sympatyk”, „pasjonat”, choć w powszechnej praktyce języka polskiego każde z tych słów ma nieco inne zabarwienie. 
i złożoność zagadnień wchodzących w skład pola badawczego. Mając na uwadze ograniczoną objętość niniejszego tekstu, omawiając wstępne zagadnienia, skupię się jedynie na tych elementach bycia fanem, które będą kluczowe dla podjętego tematu.

Fan to silnie zaangażowany odbiorca tekstu kultury ${ }^{4}$, z którym to tekstem przedmiotem uwielbienia - łączy go specyficzna, intensywna więź afektywna wytworzona przez entuzjastyczny odbiór. Ta więź wpływa na życie fana i podejmowane przez niego decyzje oraz wiąże się z różnego rodzaju inwestycjami poczynionymi wobec obiektu: emocjonalnymi, intelektualnymi, angażującymi fizycznie, czasowo i ekonomicznie (Kobus, 2018, s. 10). Fani to grupa niejednorodna. Bycie fanem należy postrzegać bardziej jako spektrum intensywności odbioru oraz wynikające $\mathrm{z}$ niego zachowania i decyzje, a nie jako układ zero-jedynkowy (fan vs. nie-fan). Pomiędzy fanami tego samego tytułu mogą występować też diametralne różnice pod względem odczytywania ulubionego tekstu i preferowanych praktyk fanowskich. Entuzjaści także w różnym stopniu angażują się w społeczności fanowskie i różnie traktują swoją tożsamość jako fanów, choć najczęściej jest to dla nich istotny czynnik składający się na narracje tożsamościowe.

Społeczności fanowskie przyjęto nazywać fandomami, zarówno przy mówieniu o określonych grupach (np. fandom serialu Hannibal), jak i o ogóle fanów jako takich; co z jednej strony może mylnie sugerować jednolitość wszystkich grup, ale też wskazuje na pewne poczucie wspólnotowości charakterystyczne dla całego tego środowiska. Zawsze jednak fan mówiący o fandomie ma na myśli większą zbiorowość, wykraczającą poza znanych mu osobiście sympatyków, z którą to zbiorowością łączy go podobieństwo praktyk, często wspólnota interesów i wartości, a co najmniej wspólny obiekt afektywnego przywiązania. Społeczności fanów przez ostatnie 50 lat zmieniały swoje struktury i sposoby funkcjonowania. Ze względu na łatwiejszy dostęp do różnych wytworów kultury spowodowany cyfryzacją jej zasobów coraz częściej można zaobserwować zjawisko multifandomingu, czyli bycia członkiem wielu fandomów jednocześnie. Środowiska i zachowania fanowskie formują się wokół różnych zjawisk i tekstów kultury na całym świecie, co oczywiście sprawia, że są niejednorodne. Nawet osoby z tego samego kregu kulturowego, ale wybierające inny przedmiot uwielbienia, będą tworzyły bardzo różne fandomy, inaczej korzystające z podobnych praktyk, wytwarzające inne dyskursy i zachowania. Dzieje się tak m.in. w przypadku zachodnich fanów zachodnich wytworów (np. fantastyki) i zachodnich fanów popkultury azjatyckiej (np. mangi i anime). Choć wiele osób należy do obu tych społeczności, to w powszechnym rozumowaniu „fan-

4 Pisząc o tekstach kultury mam na myśli wiele różnorakich zjawisk, wokół których mogą wytwarzać się grupy fanowskie, m.in. serie książek, filmy, seriale, komiksy, gry komputerowe, ale także osoby publiczne, takie jak muzycy, aktorzy, sportowcy a nawet politycy. Przyjmuję definicję bliską semiologicznemu spojrzeniu na tekst kultury jako na wytwór, w którym przejawiają się reguły społeczne oraz wzory zachowań i który może zostać poddany analizie i interpretacji. 
taści” i „mangowcy” są od siebie mocno odseparowani, czego dowodem są m.in. specjalnie wydzielone bloki atrakcji „azjatyckich” na takich imprezach, jak poznański Festiwal Fantastyki Pyrkon czy Międzynarodowy Festiwal Komiksów i Gier Komputerowych w Łodzi.

Fani swoiście „przeredagowują istniejącą rzeczywistość” (Krajewski, 2006, s. 17), ustanawiając własne systemy wartości; sprzeciwiają się obowiązującym normom kulturowym, np. finansowym (pieniądze pasjonata-kolekcjonera są wydawane na kolejne eksponaty, nie zaś na dobra powszechnie oceniane jako warte inwestycji). Jak ujął to John Storey, ,społeczność fanów przeciwstawia się codziennej bierności kulturowej »krainy pospolitości«”(2003, s. 16). Entuzjaści i złożone $\mathrm{z}$ nich środowiska ustalają własne sposoby funkcjonowania w świecie rzeczywistym, podporządkowując swoją energię, wielopoziomowe zaangażowanie i część systemu wartości (np. cenienie bardziej tych a nie innych dóbr materialnych) obiektom afektu, tym samym tworząc alternatywne wzorce praktyk kulturowych. Nie oznacza to, prócz skrajnych przypadków, oderwania od rzeczywistości, lecz odsunięcie się od normatywnych standardów jej głównego nurtu.

Fani do lat 90. XX w. często opisywani byli jako infantylni, a jednocześnie seksualnie sfrustrowani degeneraci, zarówno w opinii publicznej, jak i w tekstach pretendujących do standardów naukowych, co Piotr Siuda określił jako tzw. paradygmat dewiacji w fan studies (2010). Uznawani za zagorzałych odbiorców kultury masowej „obrywali rykoszetem” w pracach socjologicznych postrzegających kulturę popularną jako narzędzie manipulacji i kontroli społecznej ${ }^{5}$. Tego rodzaju publikacje ugruntowały elitarystyczny pogląd, zgodnie z którym popkultura (zrównana z kulturą masową) postrzegana jest jako z założenia zła, wulgarna, „niska”, a jej odbiorcy są bezwolnymi, nierozumnymi, potencjalnie groźnymi masami (perspektywa krytyków konserwatywnych) lub zostali ogłupieni i zniewoleni przez przemysł rozrywkowy (podejście krytyków progresywnych). Przy tych założeniach, niezależnie od deklarowanego poglądu krytyków, fani byli traktowani jako społeczna anomalia. Autorzy publikacji The American Monomyth, John Shelton Lawrence i Robert Jewett, analizując wpływ popkultury na odbiorców, podają przykład Charlesa Mansona, mordercy „zainspirowanego piosenką Helter Skelter Beatlesów” (1977, s. 12), a badając sympatyków Star Treka, przedstawiają praktyki fanów jako quasi-religijne, a ich samych sprowadzają do „narwanych kultystów zainteresowanych banalnymi tekstami” (s. 14-15). Trekkies ${ }^{6}$, podobnie jak entuzjaści Gwiezdnych wojen, są przez Jaya

5 Takie spojrzenie prezentowali m.in. Dwight Macdonald (2002), Herbert Marcuse (1991) oraz inni badacze ze szkoły frankfurckiej, w tym Theodor Adorno (1990) w swoim słynnym artykule O jazzie z $1936 \mathrm{r}$.

6 Co znamienne, termin trekkies na określenie fanów Star Treka wypracowała prasa, mając na myśli właśnie zbyt obsesyjnych entuzjastów filmu. $Z$ tego powodu miłośnicy serialu w opozycji zaczęli nazywać siebie trekkers. Z biegiem czasu oba te określenia zaczęły funkcjonować w fandomie, z tym że trekkies było dalej pejoratywnym terminem mającym opisywać fanów niedojrzałych, niezdolnych do krytycznej, intelektualnej refleksji, w opozycji do ,prawdziwego" fana-trekkera. Tym samym mainstreamowe narzędzie dyskredytacji fanów zostało zaadop- 
Gouldina (1985) określani jako osoby tracące swoją jednostkowość, dające się manipulować zawartej w obiektach swojego fanostwa ideologii amerykańskiego imperializmu. Tego typu opinie były powielane w innych tekstach naukowych i w dyskursie medialnym, czyniąc z popkultury i fanów łatwy obiekt szykan. Według amerykańskiej badaczki Joli Jensen postrzeganie fanów jako patologicznych jednostek lub rozhisteryzowanego tłumu było przejawem krytyki nowoczesności i związanych z nią lęków na temat szybkich przemian cywilizacyjnych (2012, s. 60), przede wszystkim tych związanych z rewolucją seksualną lat 60 . Sposób opisywania fanów zmieniał się stopniowo wraz z rozwojem nauk humanistycznych, co szerzej opisała Agnieszka Urbańczyk (2018). Badaczka podkreśla, jak przydatne dla fan studies okazały się prace Pierre'a Bourdieu. Francuski socjolog, wprowadzając pojęcie dystynkcji i habitusu, wykazał, że podział na kulturę wysoką i niską jest przejawem przemocy symbolicznej i dominacji grup uprzywilejowanych eksponujących swój kulturowy kapitał. Habitus jednostek z klasy uprzywilejowanej zakłada wyższość wyrafinowanego dystansu nad emocjonalnym odbiorem typowym dla "smaku popularnego" (Turner, 2004 s. 602-603). Tak więc praktykami służącymi zachowaniu dystynkcji, umacniającej i pogłębiającej różnice między elitą a tzw. masami, będzie pogardzanie kulturą masową/popularną, odmawianie jej cech chociażby sensotwórczych, a na gruncie akademickim dewaluowanie wartości badań nad nią prowadzonych. Bourdieu pisał, że „[n]ietolerancja estetyczna wywiera straszliwą przemoc. Niechęć do innych stylów życia prawdopodobnie stanowi jedną z najsilniejszych barier między klasami” (2005, s. 75).

W wielu definicjach i opisach zbiorowości fanowskich podkreślany jest brak hierarchii czy raczej brak ścisłych struktur organizacyjnych i regulacyjnych, co z pewnością jest czynnikiem odróżniającym fandomy od fanklubów, związków czy stowarzyszeń sympatyków7. W fandomach nie ma jawnych ośrodków władzy, takich jak zarząd, organy kontroli, osoba prezesa czy dyrektora, nie ma też żadnych komisji wpisujących lub skreślających kogoś z listy fanów. Niekiedy fantropolodzy wspominają o tzw. BNF (Big Name Fan), czyli osobach zasłużonych i/lub znanych, rozpoznawalnych wśród reszty entuzjastów ze względu na swoją szczególną aktywność, polegającą np. na drukowaniu i dystrybuowaniu fanzinów w kulturze analogowej, organizacji konwentów czy obecnie wydarzeń i działań w przestrzeni cyfrowej. W pewnych grupach fanów większym szacunkiem cieszą się też kolekcjonerzy (artefaktów lub wiedzy związanej z ulubionym tekstem) lub osoby tworzące fanworks (co jednak często zależy od tematyki tej twórczości ${ }^{8}$ ). Nie zmienia to ogólnej zasady, iż wyjściowo wszyscy

towane do tworzenia wewnętrznospołecznościowej opresji wobec „niewłaściwych” form zachowań. Choć znaczenie rozróżnienia trekkies-trekkers z biegiem lat nieco osłabło, do dziś jest ono $\mathrm{w}$ fandomie obecne.

7 Oczywiście, te istnieją w obrębie fandomów, sam jednak fandom jest pojęciem szerszym.

8 Osoby tworzące np. slash fanfiction (fanowskie opowiadania $\mathrm{z}$ wątkami homoerotycznymi, często tworzone do tekstów kultury, które w materiale wyjściowym nie poruszają tych wątków, przynajmniej w sposób jawny) w fandomie kultywującym są zazwyczaj przyjmowane nieufnie. 
fani są równi, to znaczy dołączając do społeczności, mają podobny zasób prestiżu społecznego i władzy symbolicznej. Jest to jednak tylko założenie. Uczestnicząc w życiu fandomów, po pewnym czasie można wskazać kilka niewyrażanych wprost kryteriów, które wielokrotnie decydują o tym, jak się zostanie przyjętym w konkretnym kręgu osób dzielących nasze zainteresowania, np. na konwencie, forum lub w grupie facebookowej.

Za takie kryterium można uznać wiek, i to dwojako rozumiany, czyli w ujęciu metrykalnym oraz jako liczba lat, które spędziło się w fandomie. Oba te wymiary często się ze sobą zazębiaja, szczególnie w przypadkach środowisk „długiego trwania”, takich jak fondomy Gwiezdnych wojen, komiksów superbohaterskich czy dorobku literackiego J.R.R. Tolkiena. Starszy fan, mogący pochwalić się, że był na premierze Nowej nadziei (1977), momentalnie zyskuje większy prestiżu niż osoba, która dopiero niedawno zainteresowała się franczyzą Star Wars. Dwojakie są też tego powody. Po pierwsze, w fandomach ceni się stałość uczuć względem obiektu fanostwa, która ma dowodzić silnego zaangażowania. Zaangażowanie niestałe cechuje „normika” („zwykłego” odbiorcę) lub „sezonowca” (osobę, która zainteresowała się danym wytworem tylko ze względu na jego obecną popularność). W stałości afektu względem obiektu uwielbienia fani dostrzegają istotną cechę swojej tożsamości. Popularność spowodowana np. kolejną odsłoną danej franczyzy (ekranizacją, serialem, grą itd.) może wśród „starych wyjadaczy” spowodować wręcz niezadowolenie na skutek pojawienia się nowych fanów (w ich mniemaniu „sezonowców”) i spowszechnienia obiektu sympatii (stającego się czymś „dla normików”). Dochodzi do paradoksu - fani z dłuższym stażem nie chca, by obiekt ich fanostwa był popularny, bo to „wszystko zepsuje”. Chęć zachowania własnego doświadczenia fanowskiego jako indywidualnego, niepowtarzalnego i niezwykłego jest silniejsza niż działanie na ekonomiczną korzyść franczyzy, co pokazuje, jak ważnym elementem narracji tożsamościowej dla fana jest owo doświadczenie.

Po drugie, odgórnie zakłada się, że długie bycie w fandomie wiąże się z odpowiednio dużą wiedzą na temat ulubionego tekstu kultury. Zdobywanie i pogłębianie wiedzy o obiekcie fanostwa to kolejne ważne dla entuzjastów kryterium odróżniających ich od przeciętnego odbiorcy. Fani czerpią radość z posiadanej wiedzy i szczycą się nią, uczestnicząc w tzw. „wiedzówkach” na konwentach, dyskutując o najmniejszych szczegółach serii czy przytaczając cytaty z niej. W mniemaniu wielu członków fandomów ktoś, kto nie posiada odpowiedniej, szczegółowej wiedzy o przedmiocie fanostwa, nie może nazywać się fanem. Tym samym, gdy dopiero wkraczamy $w$ dany fandom i jesteśmy osobą młodą, możemy być przez część jego uczestników traktowani nieufnie. Mówi się $\mathrm{w}$ fandomach o gatekeepingu - lekceważeniu lub wręcz odstraszaniu nowych sympatyków poprzez selektywność informacji i oparte na niej wykluczenie?.

9 W niniejszym numerze o praktykach tego typu szerzej pisze Agnieszka Urbańczyk w artykule Gatekeeping jako strategia immunizacyjna w fandomach transformujacych na przykładzie środowiska fanek Star Treka (przyp. red.). 
Choć obecnie wiele fanek i fanów jest przeciwnych gatekeepingowi, zjawisko to wciąż jest dość powszechne.

Innym wymogiem decydującym o poziomie prestiżu w wielu fandomach jest w dalszym ciągu płeć. Fandom pod tym względem (jak i pod względem tożsamości etnicznej czy seksualnej) powiela bowiem nierówności występujące w kulturze głównonurtowej (Kobus, 2018, s. 5). Dotyczy to głównie grup z przewagą - nawet tylko domniemaną - mężczyzn, w tym największych fandomów fantasy, science fiction czy gier komputerowych. Kobiety i osoby $a f a b^{10}$ w wielu sytuacjach są na wstępie traktowanie nieufnie, oskarża się je o bycie fake geek girl (dziewczyną chcącą zwrócić na siebie uwagę mężczyzn przez udawanie, że ma to samo hobby co oni), zmusza do udowodnienia swojej wiedzy o obiekcie fanostwa („Masz koszulkę z Kapitanem Ameryką? Wymień pięć serii o nim”), wyśmiewa się ich praktyki („Pewnie gra jedynie w Simsy”), dewaluuje zaangażowanie („Ogląda Star Wars tylko dla przystojnego aktora”). Fandomowy seksizm nie został jeszcze dostatecznie opisany w pracach z zakresu fan studies, szczególnie na gruncie polskim, jest to jednak temat na inną, obszerniejszą pracę.

Ostatnim kryterium prestiżu społecznego w fandomie, na jakim skupię się w dalszej części artykułu, jest sam obiekt fanostwa (często sytuowany w kontekście pytań o jego moralność) i forma ekspresji fanowskiego przywiązania. Zastrzeżenia innych fanów, co do tego, jak entuzjasta przeżywa swoje zaangażowanie, są z pewnością wyrazem napięcia między tym, co fanowskie a tym co „normalne”, to znaczy ogólnie przyjęte w duchu dominujących praktyk kulturowych. Chociaż bycie fanem stawia w centrum emocje, fandom ustawicznie negocjuje to, gdzie ma przebiegać granica dopuszczalnej ekspresji tych uczuć. Takie regulacje $\mathrm{z}$ jednej strony są potrzebne, by wewnątrz fandomu zwracać uwagę na niewłaściwe zachowanie niektórych jego członków (np. wulgarne nagabywanie cosplayerów ulubionej postaci), z drugiej służą temu, by chronić fandom od ataku z zewnątrz. Ten wątek w niniejszym artykule będzie bardzo istotny.

Ogół społeczności fanowskiej może negatywnie ocenić dany tekst kultury (jako słaby, wtórny, dziecinny itp.) i ta ocena będzie oczywiście rzutować na postrzeganie fanów owego tytułu. Fakt ten nie jest bez znaczenia, jednak w swoich rozważaniach skupiam się bardziej na wskazaniu czynników, które wywołują negatywne nastawienie $\mathrm{w}$ formie przesądu, zanim jeszcze oceniający zapozna się z danym tekstem. Mechanizmy, przez które jedne obiekty fanowskiego afektu są w społeczności fandomu postrzegane pozytywnie, a inne negatywnie często łączą się z kryteriami, które już wskazałam. Chodzi mianowicie o to, że nowy tekst kultury (albo nowa odsłona znanej już franczyzy) wzbudza sceptycyzm fanów z długim stażem ze względu na nostalgię za tekstami „starymi” lub chęć zachowania osobistego doświadczenia jako czegoś wyjątkowego. Także w sytuacji, gdy tekst zyskuje popularność głownie wśród młodych osób,

10 Skrót od assignated female at birth (pol. zakwalifikowane przy narodzinach jako płeć żeńska); termin dotyczący osób transpłciowych lub niebinarnych postrzeganych jako kobiety. 
a na dodatek kobiet, będzie z miejsca dewaluowany przez część fandomów, czego dowodem są chociażby reakcje męskiej publiczności na nową trylogię Gwiezdnych wojen lub fenomen k-popu. Z kolei wyznacznik dopuszczalnej formy ekspresji zaangażowania fanowskiego wiąże się $\mathrm{w}$ pewnym sensie $\mathrm{z}$ kategorią niemęskości, ponieważ dotyczy zachowań stereotypowo przypisywanym ekspresji kobiecej (entuzjastycznego krzyku, pisku, wybuchów radości, wzajemnego przytulania się) lub działań uznawanych za infantylne. Na podejście typowo binarno-patriarchalne (kobiety - emocje, histeria, mężczyźni - logika, wyważenie) potencjalnie nakłada się tu także eurocentryczna normatywność wyrażania emocji, opresyjna - lub co najmniej sceptyczna - wobec kultur, które się w niej nie mieszczą. Przykładem działania takiej normatywności może być fakt, że reakcje czarnoskórych fanów na premierę filmu Czarna pantera (2018) przez wielu fanów białoskórych uznawane były za zbyt dziecinne, przesadne, śmieszne.

Wreszcie sam obiekt fanostwa, jeśli wcześniej nie zostanie zakwalifikowany przez fandomowy ogół jako niemęski czy infantylny, może być uznany za odpychający ze względu na „niemoralność” tematu czy praktyk mu towarzyszących, co najczęściej wiąże się z naruszeniem pewnych norm seksualnych. Co jednak specyficzne, fandomowy ostracyzm w niektórych środowiskach w mniejszym stopniu wywołują zachowania męskiej i heteroseksualnej części sympatyków (np. w fandomie mangi i anime oglądanie hentai, seksualizacja młodych bohaterek czy nawet cosplayerek) niż praktyki, w których przeważają kobiety i osoby queerowe. Ciekawym casusem są tutaj tzw. yaoistki ${ }^{11}$, badane m.in. przez Aldonę Kobus (2018), Katarzynę Marak (2019) i Natalię Dmitruk (2019). Choć samo yaoi może zawierać elementy powodujące moralna dezaprobatę (np. relacje uznawane za toksyczne, fetyszyzacja związków gejowskich itp.), fandomowa stygmatyzacja „tych wstrętnych yaoistek” najczęściej nie koncentruje się na treściach moralnie wątpliwych, ale na „zbyt głośnym” zachowaniu na konwentach, otwartym mówieniu fanek o swoich fantazjach romantyczno-erotycznych i na tym, że „lubią gejów”. W tym przypadku następuje szczególne nagromadzenie kryteriów, które sytuują yaoistki w dolnych partiach fandomowej drabiny społecznej. Za niską pozycję członków tej grupy odpowiada „niemęska” ekspresja, młody wiek, przewaga kobiet oraz mało znany obiekt fanostwa, którego tematyka nie wpisuje się w ogólnie przyjętą heteronormatywność, a zarazem jest moralnie dwuznaczna. W podobnej sytuacji, choć różni ich wiek i płeć, znajdują się bronies, czyli nastoletni lub dorośli mężczyźni będący fanami serialu $M y$ Little Pony. Przyjaźn to magia. Im także zarzuca się zachowania etycznie naganne (np. tworzenie erotycznych fanworks, które mogą zostać znalezione w internecie przez dzieci - docelowych odbiorców serii) (Bajor, 2015), ale poczucie przewagi moralnej często jest tu zarazem narzędziem symbolicznej przemocy wobec wyłamujących się ze schematów męskości bronies, postrzeganych jako osoby zniewieściałe, zdziecinniałe lub wprost dewianci - w końcu obiektem

11 Yaoistki to wielbicielki yaoi, czyli mang i anime $\mathrm{z}$ wątkiem romansowym, którego bohaterami są postacie męskie. 
ich silnych afektów są rysowane w pastelowych kolorach kucyki. Bronies jako kulturowy fenomen niekiedy pojawiają się w głównonurtowych mediach, gdzie niezmiennie przedstawiani są w sensacyjnym tonie, co tylko podsyca negatywny stosunek do nich wśród reszty fandomów. Tym samym fani kucyków mają niekiedy mniejszą styczność z osobami spoza swojej grupy lub nie ujawniają się w innych środowiskach fanowskich, a także poza tymi środowiskami (np. w miejscach pracy).

Jeśli skumulujemy czynniki niskiej pozycji w fandomowej hierarchii występujące u yaoistek i bronies („niemęskość” zainteresowań i ekspresji, młody wiek, wykraczanie poza heteronormatywność, potencjalnie problematyczny/uznawany za dewiacyjny obiekt afektu, dość zamknięte środowisko), otrzymamy prawie pełną listę powodów ostracyzmu, z jakim spotyka się grupa, na której chciałabym się skupić w kolejnej części tekstu, a mianowicie furasów. Dalsze rozważania należy jednak zacząć od nakreślenia ogólnej charakterystyki tej społeczności fanowskiej.

Termin furry, określający osoby szczególnie zainteresowane postaciami antropomorfizowanych zwierząt (Gerbasi, 2008, s. 198), zaczął pojawiać się w amerykańskiej prasie fanowskiej w połowie lat 8o. XX w. W sztuce i literaturze sama konwencja przedstawiania zwierząt z cechami ludzkimi jest oczywiście dużo starsza (wystarczy wspomnieć bajki Ezopa z VI w. p.n.e.), a od początku istnienia komiksu czy animacji, chętnie przez te media wykorzystywana, zarówno w produkcjach dla dzieci (filmy Disneya), jak i dorosłych (np. komiks Krazy Kat). Jednak z powodu sukcesu dzieł takich jak disneyowski Bambi, od drugiej połowy XX w. produkcje ze zwierzęcymi bohaterami zaczęto kojarzyć głównie z odbiorcami dziecięcymi. Fandom furry intensywnie kształtował się w latach 70. XX w. na gruncie amerykańskiego komiksu undergroundowego, gdzie zwierzęce postacie występowały często w historiach z wątkami erotycznymi (np. Omaha, The Cat Dancer) i innych „dorosłych” treściach, które nie mogły w tym czasie być prezentowane w komiksach głównonurtowych z powodu cenzury (wynikającej z The Comics Code Authority z $1954 \mathrm{r}^{12}$ ). Z przytoczonych faktów historycznych wyłania się główna oś napięć, które w członkach innych fandomów i osób z zewnątrz wywołują niechęć do furasów - napięć między kojarzoną z dzieciństwem konwencją a treściami dla dorosłych. Piotr Fortuna, który badał narracje o fandomie futrzaków obecne w mediach głównonurtowych (magazyn ,Vanity Fair”, serial CSI: Kryminalne zagadki Las Vegas), ujął to następująco:

Jeśli w świecie ponowoczesnym istnieją tylko narracje, a każda z tych narracji jest równie uprawniona, to z punktu widzenia ideologii akcep-

12 Od momentu wzrostu popularności komiksów w Stanach Zjednoczonych, to jest od lat 30. XX w., wiele środowisk konserwatywnych i kościelnych widziało w komiksach elementy, które miały deprawować dzieci i młodzież - nagość, przemoc, poruszanie tematu alkoholu i narkotyków itp. Protesty owych grup nasiliły się po II wojnie światowej i doprowadziły do powstania ustawy kontrolującej treści w komiksach sprzedawanych w mainstreamie. 
towalne jest właściwie wszystko, co daje się opowiedzieć. Pleasures of the Fur sugerują, że nie sposób stworzyć składną opowieść o futrzakach. Do podobnych wniosków skłania Fur and Loathing: tutaj furries udaje się wprawdzie pokazać, ale nie zrozumieć, i jedynym sposobem na poradzenie sobie z problematycznymi bohaterami jest symboliczne wymazanie ich z rzeczywistości. Społeczne wykluczenie odmienności to tylko jedna strona medalu. [...] Prawdziwym atutem takich obrazów okazuje się ich nieredukowalność do jakichkolwiek odpowiedzi, całkowita bezradność języka, splątanie opozycji (kreskówki, ale dorosłość - perwersja, ale dziecięcość - niewinność, ale popędliwość - natura, ale sztuka itd.). Ten nacisk na podtrzymanie tajemnicy widać $\mathrm{w}$ stereotypach wytwarzanych przez porządek symboliczny (2015, s. 132).

Choć można wskazać wiele tekstów kultury, które są przez futrzaków darzone szczególną sympatią (np. animowany Robin Hood czy Król Lew Disneya), to przedmiot ich fanostwa nie jest tak prosty do określenia. Praktyki furry koncentrują się najczęściej wokół postaci antropomorficznych zwierząt lub stworzeń fantastycznych, które są kreowane przez samych uczestników fandomu ${ }^{13}$. Takie postacie przyjęło się nazywać fursonami (połączenie angielskich słów furry i persona). Jak podaje serwis WikiFur, istnieją różne stopnie identyfikacji fana $\mathrm{z}$ jego fursoną: od bohatera kreowanego do konkretnego rysunku czy sesji role-play, po „wewnętrzne, bardziej zwierzęce alter ego lub obiekt do naśladowania dla danej osoby należącej do społeczności furry" (WikiFur, a). W polskojęzycznym haśle Fursona czytamy również, że „dla niektórych futrzaków [fursona] może być też ich prawdziwą duszą uwięzioną w ludzkim ciele” (WikiFur, a). I choć wersja anglojęzyczna zaznacza, że „furasowy styl życia czy zwierzęcy totemizm nie są nierozerwalnie związane z koncepcją fursony” (WikiFur, b), to jednak upodobanie do terantropii przypuszczalnie cześciej spotykane jest w społeczności futrzaków niż w innych grupach fanowskich (Robertson, 2012). Poza tym furasy wykonują szereg praktyk obecnych także w pozostałych fandomach: rysują fanarty i komiksy z fursonami, piszą role-play i fanfiction, organizują swoje konwenty, tworzą wideoklipy, playlisty czy inne rodzaje fanworks. Wyróżniające dla tej grupy jest natomiast tworzenie fursuitów - zabudowanych futrzastych przebrań zaantropomorfizowanych zwierząt (najczęściej swoich furson), zasłaniających całe ciało, łącznie z twarzą, dłońmi i stopami. Przebierając się w fursuit fan niekiedy naśladuje, „wciela się" (podobnie jak to ma miejsce $\mathrm{w}$ cosplayu) w przedstawione za pomocą stroju stworzenie. Przez swoje przebranie futrzaki często wprawiają osoby postronne w konsternację: fursuity to „nieprzeniknione supermaski, nie tylko zasłaniające twarz, lecz uniemożliwiające nawet rozpoznanie płci osobnika”, które pozwalają „zatajać społeczną tożsamość oraz unikać zobowiązań interakcyjnych” (Fortuna, 2015, s. 130). Furasy,

13 Jeden $\mathrm{z}$ organizatorów konwentu furrysów (tzw. konfurencji) ujął to w sposób następujący: „Jesteśmy fanami siebie nawzajem” (Dickinson, 2010). 
zgodnie z freudowskim ujęciem niesamowitości, wywołują niepokój, wpisując się w hipotezę Uncanny Valley ${ }^{14}$, albo też stają się obiektem żartów w rodzaju „Pewnie wąchają sobie tyłki jak psy”. Także ekspresja furasów na konwentach, która jest bardziej bezpośrednia w porównaniu ze standardowymi zachowaniami fanów i odbierana jako swoiście zezwierzęcona - „drapią się po plecach, oporządzają się jak makaki w zoo” (Fortuna, 2015, s. 124) - może być dla innych odpychająca.

Prawdopodobnie każda liczniejsza grupa fanowska, do której należą nastolatki i osoby dorosłe, produkuje treści erotyczne, w każdej też trudno oszacować, jaki procent aktywności fanów stanowi tego typu twórczość. Nie inaczej jest w przypadku fandomu furry, choć ten, podobnie jak yaoistki i bronies, jest kojarzony głównie z twórczością erotyczną oraz praktykami seksualnymi (zbiorczo nazywanymi yiff), które oceniane są jako niewłaściwe, przesadne, szkodliwe, w najlepszym wypadku nienormatywne. Można zauważyć, że wśród furasów czéściej spotyka się mniejszości seksualne (Dickinson, 2010), ale też przedstawicieli różnych parafilii czy ideologicznych ekstremistów. Sami członkowie fandomu furry często podkreślają, że stanowią otwartą i wspierającą się grupę, i być może właśnie dlatego ku nim ciążą jednostki w innych fandomach odrzucone.

Naruszanie norm społecznych związane z samym istnieniem i niektórymi praktykami można przypisać wielu fandomom (jako grupom przeredagowującym po swojemu rzeczywistość). To jednak furry narusza - lub jest posądzony o naruszenie - tabu, które może być uznawane za podstawowe, a mianowicie tabu antroponormatywności. O ile inne fandomy wytwarzają przekaz typu: „Nie musisz być człowiekiem, który wpisuje się w schemat biernego i niezaangażowanego odbiorcy kultury”, to furry można przypisać przekaz: „Nie musisz w ogóle być człowiekiem”. To jednak narracja, która ma swoje rzeczywiste odzwierciedlenie jedynie w skrajnych przypadkach i projektowanie jej na cały fandom dowodzi tylko, że nawet lekkie naruszenie antropocentryzmu spotyka się z oporem innych grup.

Furry posądzani są zbiorczo o zoofilię, choć trudno w antropomorficznych rysunkach zwierząt o ludzkich charakterach dopatrzeć się bezpośredniego związku z ich rzeczywistymi odpowiednikami. Wpisanie całej społeczności furry w naganną praktykę seksualną lub chociażby związaną z nią problematykę (np. pytanie o to, czy furrysowe rysunki normalizują zoofilię i mogą do niej zachęcać) sprawia, że tym łatwiej umieścić futrzaków na samym dole fandomowej hierarchii, czyniąc $z$ nich kozła ofiarnego.

Ujęty w ramy teoretyczne przez francuskiego historyka Rene Girarda mechanizm kozła ofiarnego to mający długą tradycje sposób utrzymania porządku i tożsamości danej grupy. Wywodzi się od starożytnego, opisywanego już w Starym Testamencie, ale prawdopodobnie pochodzącego z dawnej Anatolii,

14 „Dolina niesamowitości” to hipoteza naukowa stosowana głównie w robotyce. Wg tej hipotezy obiekty niebędące ludźmi (np. roboty), ale do ludzi podobne, wywołują u obserwujących uczucie niepokoju lub nawet odrazy. Wywołane jest to działaniem ludzkiego mózgu zaważającym niemal nieświadomie drobne różnice w zachowaniu takiego obiektu. 
rytuału oczyszczenia, polegającego na symbolicznym przelaniu grzechów społeczności na wybrane zwierzę, które jest następnie wypędzane i/lub składane w ofierze. W obliczu kryzysu zbiorowość szuka ofiary, jednostki lub podgrupy szczególnie się wyróżniającej, którą można oskarżyć o naruszenie zasad. Jerzy Klimczak streszcza teorię Girarda następująco:

[Girard] analizując „teksty prześladowcze”, czyli poddane zniekształceniom przez prześladowców sprawozdania o kolektywnych aktach przemocy spisywanych przez samych oprawców, wyróżnia cztery podstawowe stereotypy prześladowcze. Pierwszym z nich jest stereotyp kryzysu „odróżnorodnienia” polegający na utracie zróżnicowania oraz chyleniu się ku upadkowi formacji kulturowych. Kryzys ten ma przede wszystkim charakter społeczny a objawia się rozkładem stosunków międzyludzkich. Znamionującymi ów kryzys są również tendencje do tłumaczenia go przyczynami społecznymi (przede wszystkim moralnymi) oraz obwinianie o zaistniały stan rzeczy grup bądź jednostek, które postrzegane są za szczególnie niebezpieczne. Drugi stereotyp można nazwać stereotypem „oskarżycielskim”. Charakteryzują go głównie trzy rodzaje zbrodni, o które są oskarżane ofiary. Pierwszym z nich są wszelkiego rodzaju akty gwałtu na istotach, wobec których tego rodzaju postępowanie jest uważane za czyn najbardziej zbrodniczy. Sprowadzają się one do zbrodni przeciwko najwyższym autorytetom (król, ojciec, Bóg) oraz w społecznościach biblijnych i nowożytnych przeciw najsłabszym (kobiety, dzieci). Do drugiego rodzaju zbrodni należą: sodomia, gwałty, kazirodztwo oraz naruszenie ściśle przestrzeganego tabu danej kultury. Uogólniając, zbrodnie te możemy określić mianem zbrodni na tle seksualnym. Ostatni rodzaj to zbrodnie dotyczące religii, do których również możemy zaliczyć przekraczanie tabu oraz na przykład profanację hostii. Wszystkie te zbrodnie są skierowane przeciwko podstawom kulturowego porządku. Stereotyp selekcji ofiarniczej stanowi trzeci stereotyp prześladowczy. Dotyczy on mniejszości przede wszystkim etnicznych i religijnych a sam w sobie stanowi zasadę transkulturową. Obok kryteriów kulturowych i religijnych występują tutaj również kryteria fizyczne takie jak wady genetyczne, obłęd, choroba czy kalectwo. Sama ułomność według Girarda jest wpisana nierozdzielnie w zespół cech ofiarniczych, a każdy, kto ma trudności w adaptacji do jakiejś grupy traktowany jest przez jej członków jako ułomny. Czwartym stereotypem prześladowczym jest sama przemoc (2011, s. 40-41).

Choć analogia praktyk fanowskich do religijnych rytuałów oczyszczenia jest daleka, czytając powyższy fragment, można wskazać pewne elementy koncepcji Girarda pasujące do przedstawianej przeze mnie hipotezy. Stereotyp „odróżnorodnienia”, wynikający z poczucia zagrożenia tożsamości, na gruncie fandomowym może być odbiciem napięć, jakim ulegają społeczności entuzjastów. 
Chodzi tu o zlewanie się fanów i „normików”, o coraz większą widoczność praktyk fandomowych w mainstreamie i rozpowszechnienie fanowskiego modelu odbioru tekstów kultury odczuwane jako niebezpieczeństwo utracenia swojej wyjątkowej tożsamości, a jednocześnie o narażenie grup fanowskich na atak z zewnątrz. To ostatnie nie jest zresztą odczuciem zupełnie oderwanym od rzeczywistości, co możemy stwierdzić, gdy pokrótce prześledzimy historię ruchów fanowskich, a także zdamy sobie sprawę z tego, że sposób myślenia o fanach jako patologii, choć w mniejszym natężeniu, nadal jest obecny w publikacjach naukowych czy prasowych. Figura histerycznego i nieracjonalnego, a przez to groźnego fana jest widocznie potrzebna jako negatyw znormalizowanego, preferowanego odbioru również w XXI w. Tym samym fani w wielu środowiskach dalej czują się zagrożeni oskarżeniami o nienormalność i perwersyjność, a poczucie zagrożenia lub potrzeba, by znaleźć kogoś gorszego od siebie, może sprawiać, że szukają właśnie kozła ofiarnego. Michał R. Wiśniewski w felietonie Nasi bracia mniejsi ujął to następująco:

Tak naprawdę mangowcy i furrysi jadą na tym samym wózku. Chociaż oni mają bardziej przegwizdane. Mangowcy mają łatkę zboczeńców z powodów hentajów [hentai to mocno erotyczne mangi i anime - A.S.]. Furrysi - z powodu yiffania. [...] Tak, dla większości furrysów te przebieranki i fanarty są seksualnym fetyszem. Jeśli jesteście mangowcami, to przyjmiecie to bez mrugnięcia okiem - ileż my mamy różnych fetyszy, od mundurków szkolnych zaczynając! Ale mamy sporo szczęścia - udało się (po latach walki) wybudować mur między hentai a anime mainstreamowym. Jest dużo tytułów, które można pokazać „normalnym” ludziom i nie narazić się na łatkę zboczeńca. Furrysi nie mają niczego takiego, głównonurtowe antropo [przedstawienie antropomorficzne zwierząt - A.S.] jest zajęte przez bajki dla dzieci i nikt nie uważa tego za „sztukę furry” [...]. Każdy prześladowany fandom potrzebuje subfandomu, który będzie prześladował. Mainstream dokucza fantastom. Fantaści graczom i mangowcom. My, mangowcy, byliśmy na samym dnie. I tu - nagle! - pojawiają się furrysi, na których można się wyżyć - już nie jesteśmy najgorsi! Ściekająca z góry przemoc (2014b, s. 74).

Wiśniewski, choć również powiela stereotypy na temat furry, wskazuje na istotną kwestię - obiekty fascynacji wielu innych fandomów również można postrzegać jako fetysze. Innymi słowy, tożsamość fanowska i seksualna nie zawsze są w pełni oddzielone, choć ze względu na obowiązującą normatywność fani wolą ukrywać ten fakt i znaleźć podgrupę, którą będą oskarżać o „zbrodnie na tle seksualnym” popełniane na najsłabszych (napastowanie zwierząt) oraz o łamanie społecznych normy i tabu. Sytuacja ta ma jeszcze dodatkowy aspekt. Jeśli bowiem fandom furry faktycznie przyciąga osoby, które w pozostałych grupach mogą czuć się wykluczone ze względu na swoją seksualność czy tożsamość, to tym bardziej niechęć innych będzie się koncertować na tej 
właśnie społeczności. Dystans wobec furry, nie dość że w pewnym sensie jednoczy różne fanowskie grupy, wzmacniając poczucie ponadfandomowej wspólnoty, to jest jeszcze wentylem fantazjowania o przemocy - strzelania do furasów i „utylizowania” ich. Wątpliwe, by owe fantazjowanie ziściło się kiedyś w rzeczywistości pozainternetowej, większość praktyk fandomowych ma bowiem miejsce w przestrzeni wirtualnej, tam też mogą spotkać futrzaków szykany czy niewybredne żarty.

Dokładne zbadanie ostracyzmu, jakiemu podlegają przedstawiciele furry, nie jest łatwe ze względu na szereg warunkujących go czynników, takich jak nietypowość i rozproszenie przedmiotu fanostwa, względnie zamknięte środowisko, z którego do ogólnego obiegu przedostają się informacje o szczególnie nagannych (lub za takie uważanych) zachowaniach, ale przede wszystkim faktyczne i domniemane konotacje związane z nienormatywną ekspresją i seksualnością. Tym samym w wielu przypadkach niechęć do furrysów, połączoną z brakiem osobistej znajomości tego fandomu i jego przedstawicieli, można uzasadnić ogólnie przyjętą moralnością, bo przecież w ostateczności da się zaakceptować dziwne stroje, zachowania czy nieheteronormatywność, ale nie zoofilię. Poczucie wyższości moralnej jest tu elementem przemocy symbolicznej.

Ale popkultura nie stoi w miejscu i zaczyna czerpać inspiracje również ze zjawisk, które występują na jej obrzeżach. O ile rację miał Wiśniewski piszący w 2014 r., że w głównym nurcie brak historii o uczłowieczonych zwierzętach, które nie byłyby „bajkami dla dzieci”, to w przeciągu zaledwie pięciu lat sytuacja ta istotnie się zmieniła. Serial animowany dla dorosłych BoJack Horseman (2014-2020), którego głównym bohaterem jest zachowujący się jak człowiek koń, zdobył szereg nagród i uznanie krytyków. Także wyprodukowany przez platformę Netflix mini-serial Wodnikowe wzgórze (2018) odświeżył zainteresowanie prozą Richarda Adamsa o tym samym tytule, wymienianą jako jedna z istotniejszych powieści dla fandomu furry. Na rynku komiksów dla dorosłych ukazały się takie tytuły, jak Mysia straż (2006-2014) i Wbrew naturze (2017-2018). Z kolei wśród mang i anime pojawiło się Dziecię bestii (2018), Beastars (2016-2020) i Brand New Animals (2020), a autor Dziewczynki w krainie przeklętych, Nagabe, wprost określa się jako futrzak i tworzy komiksy furry (np. The Wize Wize Beasts of the Wizarding Wizdoms, 2019). Są to być może pierwsze zwiastuny zmian, jakie w najbliższej przyszłości spotkają omawiany fandom, jeśli motywy antropomorficznych zwierząt będą nadal pojawiać się tak licznie. Jest ku temu kilka przesłanek, związanych z występującymi w wymienionych produkcjach tematami. Zwierzęcy wygląd bohaterów to często pretekst do dowcipów i gier słownych, ale też okazja do przedstawiania alternatywnych wizji społeczeństwa, w którym występuje ogromna różnorodność gatunkowa i związane z nią problemy (chociażby konflikt na linii mięsożercy-roślinożercy). Pod tym względem produkcje z motywami furry można porównać do klasycznych tekstów science fiction eksplorujących wizję istnienia cywilizacji różnych od ziemskiej lub koegzystencję ludzi i robotów. Przemiany w popkulturze ostatnich dekad mogą sprawić, że postacie furry staną się - podobnie jak ich ezopowi 
poprzednicy - bohaterami alegorii, w tym przypadku poruszających kwestie społecznego zróżnicowania.

Pomijając jednak kreatywne możliwości wynikające z antropomorfizacji zwierząt, dostrzeżenie furry przez twórców i producentów głównego nurtu jako ekonomicznie opłacalnego rynku zbytu przyczyni się zapewne do upowszechnienia treści skierowanych do tego typu odbiorców. Większa ilość rozpoznawalnych tekstów kultury z elementami furry, pociągająca za sobą np. produkcję gadżetów lub nawet fursuitów, może istotnie zmienić sposób funkcjonowania środowiska futrzaków, a także przyczynić się do wzrostu ich znaczenia w fandomowej hierarchii.

\section{BIBLIOGRAFIA}

Adorno, T. W. (1990). On Jazz (trans. J.O. Daniel). Discourse, 12(1), 45-69.

Bajor, J. (2015). Między bajka a perwersja - pornografia i erotyka fanowska w środowisku internetowym na przykładzie fandomu My Little Pony: Przyjaźn to Magia. Praca Magisterka: Uniwersytet Warszawski.

Bourdieu, P. (2005). Dystynkcja. Społeczna krytyka władzy sq̨dzenia (przeł. P. Biłos). Warszawa: Wydawnictwo Naukowe Scholar.

Dickinson, E. J. (2010). Will Furries Ever Go Mainstream? Retrieved from: https://www.rollingstone.com/culture/culture-features/furries-midwest-furfest-mainstream-932924/

Dmitruk, N. (2019). Fanki „yaoi” na gruncie polskim. Miejsce „yoaistki” w fandomie mangi i anime. W: D. Brzostek, A. Kobus, K. Marak \& M. Markocki (red.), „Chińskie bajki”. Fandom mangi $i$ anime w Polsce (s. 117-136). Toruń: Wydawnictwo Naukowe UMK.

Fortuna, P. (2015). Mroczny przedmiot przytulania. O kontrowersyjnych wizerunkach fandomu futrzaków w kulturze popularnej. Przegląd Humanistyczny, 45o(3), 127-134.

Gerbasi, K. (2008). Furries from A to Z (Antropomorphism to Zoomorphism). Society and Animals 16(3), 197-222. doi: 10.1163/156853008X 323376

Goudlin, J. (1985). Empire, Aliens, and Conquest: A Critique of American Ideology in Star Trek and Other Science Fiction Adventures. Toronto: Sisyphus Press.

Jewett, R., \& Lawrence J. S. (1977). The American Monomyth. New York: Anchor Press.

Jensen, J. (2012). Fandom jako patologia. Konsekwencje definiowania. Pantoptikum 11, 56-71.

Klimczak, J. (2011). Kozioł ofiarny jako strategia oswajania obcego. Społeczne strategie postępowania w obliczu pandemii na przykładzie HIV/AIDS. W: A. Pawlak \& R. Mielczarek (red.), Media $i$ zdrowie w doświadczeniach codziennych i granicznych (s. 38-52). Łódź: Uniwersytet Medyczny.

Kobus, A. (2018). Fandom. Fanowskie modele odbioru. Toruń: Wydawnictwo Naukowe Uniwersytetu Mikołaja Kopernika.

Kobus, A. (2019). Opowiadanie „yaoi”. Hybrydowe gatunki w polskiej twórczości fanowskiej. W: D. Brzostek, A. Kobus, K. Marak \& M. Markocki (red.). „Chińskie bajki”. Fandom mangi i anime w Polsce (s. 157-180). Toruń: Wydawnictwo Naukowe UMK.

Krajewski, M. (2006). POPamiętane. Gdańsk: Wydawnictwo Słowo/Obraz Terytoria.

Macdonald, D. (2002). Kultura masowa (przeł. C. Miłosz). Kraków: Wydawnictwo Literackie.

Marak, K. (2019). Mangi „yaoi” w Polsce. Charakterystyka fandomu. W: D. Brzostek, A. Kobus, K. Marak \& M. Markocki (red.). „Chińskie bajki”. Fandom mangi i anime w Polsce (s. 137-156). 
Toruń: Wydawnictwo Naukowe UMK.

Marcuse, H. (1991). Człowiek jednowymiarowy. Badania nad ideologia rozwiniętego społeczeństwa przemystowego (przeł. S. Konopacki). Warszawa: Państwowe Wydawnictwo Naukowe.

Patten, F. (2017). Furry Fandom Conventions. 1989-2015. Chicago: McFarland.

Robertson, V. L. D. (2012). The Law of the Jungle: Self and Community in the Online Therianthropy Movement. Pomegranate. The International Journal of Pagan Studies, 14(2), 256-280. doi: 10.1558/pome.v14i2.256

Siuda, P. (2010). Od dewiacji do głównego nurtu. Ewolucja akademickiego spojrzenia na fanów. Studia Medioznawcze, 42(2), 87-99. doi: 123456789/993

Storey, J. (2003). Studia kulturowe i badania kultury popularnej. Teorie i metody (przeł. J. Barański). Kraków: Wydawnictwo Uniwersytetu Jagiellońskiego.

Turner, J. H. (2004). Struktura teorii socjologicznej (przeł. G. Woroniecka). Warszawa: Wydawnictwo Naukowe PWN.

Urbańczyk, A. (2018). Subwersja, nie sztuka. Korzenie, założenia i problemy fan studies. Przestrzenie Teorii, 29, 261-275.

WikiFur. (a). Fursona. Retrieved from: https://pl.wikifur.com/wiki/Fursona

WikiFur. (b). Fursona. Retrieved from: https://en.wikifur.com/wiki/Fursona.

Wiśniewski, M. R. (2014a). Jetlag. Warszawa: Wydawnictwo Krytyki Politycznej.

Wiśniewski, M. R. (2014b). Nasi bracia mniejsi. Arigato, 21, 74. 
